\title{
The Mythisation of the Holocaust
}

\author{
Rybak, K. (2019). Dzieciństwo w labiryncie getta. Recepcja \\ mitu labiryntu w polskiej literaturze dziecięcej o Zagładzie. \\ Wydawnictwa UW.
}

\section{Abstract:}

The author of this review article critically discusses the book Dziecinstwo w labiryncie getta. Recepcja mitu labiryntu w polskiej literaturze dziecięcej o Zagładzie [Childhood in the Labyrinth of the Ghetto: Reception of the Labyrinth Myth in Polish Children's Literature about the Holocaust] by Krzysztof Rybak (2019). She examines the monograph in the context of, inter alia, the research already conducted in the field, literary works, architecture, memorials, the Holocaust victims', survivors', and witnesses' testimonies, as well as in relation to the possible symbolic links of the Shoah and the antiquity. The paper's conclusion is that children's literature can hardly prevent the mythisation of the Holocaust, but Rybak's book proves beyond doubt the perseverance of myth. The banalisation, simplification, and trivialisation of the Shoah, as well as the issues of appropriateness and memory, are also important concepts that frame the author's reflections presented in this paper.

Key words:

classical reception studies, Holocaust, Krzysztof Rybak, labyrinth, myth, Polish children's literature

* Katarzyna Jerzak - PhD, Professor in the Department of Modern Languages at the Pomeranian University in Słupsk (Poland). Her research interests are literary and artistic representations of exile and peregrination. Contact: katarzyna.jerzak@apsl.edu.pl. 


\section{Mityzacja Holokaustu}

Rybak, K. (2019). Dzieciństwo w labiryncie getta. Recepcja mitu labiryntu w polskiej literaturze dziecięcej o Zagładzie. Wydawnictwa UW.

\section{Abstrakt:}

Autorka artykułu recenzyjnego krytycznie omawia książkę Dzieciństwo w labiryncie getta. Recepcja mitu labiryntu w polskiej literaturze dziecięcej o Zagładzie autorstwa Krzysztofa Rybaka (2019). Rozpatruje monografię w kontekście m.in. już przeprowadzonych badań w tej dziedzinie, dzieł literackich, architektury, miejsc pamięci, świadectw ofiar, ocalałych i świadków Holokaustu, a także w odniesieniu do możliwych symbolicznych związków Zagłady i starożytności. Konkluzja artykułu jest taka, że literatura dziecięca nie jest w stanie zapobiec mityzacji Holokaustu, ale książka Rybaka dowodzi ponad wszelką wątpliwość trwałości mitu. Istotnymi pojęciami tworzącymi ramę dla rozważań autorki artykułu są też banalizacja, symplifikacja i trywializacja Shoah, jak również kwestie odpowiedniości i pamięci.

\section{Słowa kluczowe:}

studia recepcją antyku, Zagłada, Krzysztof Rybak, labirynt, mit, polska literatura dziecięca

It is more and more difficult for us to imagine the real, History, the depth of time, or three-dimensional space, just as before it was difficult, from our real world perspective, to imagine a virtual universe or the fourth dimension.

Jean Baudrillard, "Disneyworld Company"

7 he post-World War II generations are distant enough from the Shoah to 1 witness the gradual dilution of its meaning. ${ }^{1}$ To write post-factum about the Warsaw - or any other - Ghetto using the labyrinth as a metaphor is to admit that we, the non-survivors of the Shoah, have little idea of what it meant

1 In a recent book review (discussing Czyja dzisiaj jest Zagłada? Retoryka - ideologia - popkultura [Who Does the Holocaust Belong to Today? Rhetoric - Ideology - Pop Culture] by Marta Tomczok, 2017), the literary critic and comparative literature professor Marcin Wołk (2019) writes: "Readers with the syndrome of the Holocaust's uniqueness will not be filled with optimism when reading Tomczok's new book. It makes us realise that we are a declining species with our 'second-generation' approach to the representation of the Shoah - as the ones who believe that we should write about It only in a documentary, factual manner, and if in a literary mode, then carefully selecting and measuring artistic means as if in a pharmacy so as not to violate the importance of the subject. And what is worse, that in the 
to have lived in the ghetto. ${ }^{2}$ Myth offers distance. The heroes and heroines of myths die mythical, i.e. unreal, deaths. Could Mordechai Tsanin, the author of Iber shteyn un shtok: a rayze iber hundert khorev gevorene kehiles in Poyln [Of Stones and Ruins: A Journey Through One Hundred Destroyed Communities in Poland] (I use its Polish translation herein - Canin, 1952/2018) return from his journey to Poland in 1947 to write a children's book about the Warsaw Ghetto? ${ }^{3}$ In 1977, children's books author Eric A. Kimmel wrote: "To put it simply, is mass murder a subject for a children's novel? Five years ago, we might have said no; ten years ago we certainly would have. Now, however, I think the appearance of a novel set in the center of the lowest circle [of hell, i.e. death camps] is only a matter of time" (p. 91; as quoted in Franklin, 2018). Thus, the banalisation of the Holocaust is what concerns us here: a progressive stripping a real event of its original character, its simplification and trivialisation. In the United States, where according to a recent survey only $53 \%$ of young people knew what the 'Nazi-created ghettos' were (Pew Research Center, 2020), Jane Yolen in her 2018 Mapping the Bones can tell the story of fictitious twins from the Lodz Ghetto who end up in a death camp as a fractured Hansel and Gretel fairy tale. But to write about the Warsaw Ghetto in Poland, in Warsaw, is what Jacek Leociak (2009/2019, p. 36) has called an "urbanized" form of experience, ${ }^{4}$ and therefore carries a particular moral obligation, one that Marek Edelman called for in $1945 .{ }^{5}$ Krzysztof Rybak's (2019) first book, Dziecinstwo w labiryn-

process we are witnessing today - that is, in which we are involuntary participants - not only does this approach to the Holocaust disappear, but the Holocaust itself dissolves as a unique event that eluded categorisation, permanently marking the history of humanity" (p. 379-380). (All translations, if not otherwise indicated, are made by the author of the paper - Katarzyna Jerzak).

2 Małgorzata Wójcik-Dudek (2020), in her thorough, well-taken review of Krzysztof Rybak's book, quite appropriately quotes Sławomir Buryła (2016): "The death of the last witnesses of the Shoah will make the Holocaust appear in the field of reflection of contemporary culture and art as a mediated experience [...]. The concept of appropriateness [...] will become increasingly liberalised, leading to more and more freedom in the choice of means of artistic expression" (pp. 81-82).

3 "After all, I knew the streets and alleys of Warsaw so well, knew every corner of the Jewish district. And now I'm not sure where Dzika and Dzielna streets were and where were Nalewki” (Canin, 1952/2018).

4 Leociak (2009/2019) discusses "the urban as a category of human community in the social, cultural and existential sense" (p. 36).

5 "On May 10 $0^{\text {th }}, 1943$, the first period of our bloody history, the history of the Warsaw Jews, came to an end. The site where the buildings of the ghetto had once stood became a ragged heap of rubble reaching three stories high. Those who were killed in action had done their duty to the end, to the last drop of blood that soaked into the pavements of the Warsaw 
cie getta. Recepcja mitu labiryntu w polskiej literaturze dziecięcej o Zagładzie [Childhood in the Labyrinth of the Ghetto: Reception of the Labyrinth Myth in Polish Children's Literature about the Holocaust], ${ }^{6}$ is an attempt to demonstrate how contemporary Polish literature for children and young adults struggles, as it were, to fill the metaphysical void, while his argument anchors his method in classical mythology reception studies.

The survival of the Nazi-created ghetto is thus a vanishing experience. Even the very word ghetto, which in Europe, and especially in Poland, has the deadly connotation of being part of the Nazi killing machine - Benjamin Paloff (2017) writes that "notably, the German administration regarded the Ghetto as its own urban space containing a concentration camp," which suggests that both death camps and ghettos were part of the same extended killing space - had already come to mean other urban spaces, principally the inner city African-American enclave, reclaimed in recent years as the space of renewal. ${ }^{7}$ When one types 'ghetto labyrinth' into the Google search engine these days,

Ghetto. We, who did not perish, leave it up to you to keep the memory of them alive - forever" (M. Edelman, 1945/2004).

6 The book's author also led a research project on a similar topic, Oczami dziecka. Zagłada w polskiej literaturze dziecięcej i młodzieżowej po roku 1989 [Through the Eyes of a Child: The Holocaust in Polish Children's and Young Adult Literature after 1989], which resulted in, among others, an internet database (Rybak, 2016-2020).

7 My 16-year-old son pointed out to me that even in Poland the word getto has now an Americanised meaning, as in the lyrics of the Polish rapper Kali's (Marcin Kamil Gutkowski's) 2018 song "30 KMH": "I have not lived here for a long time now, but the ghetto will always remain my home / Here I left a piece of my heart, I built here my totem." The song's video has over 63 million views on YouTube (https://www.youtube.com/watch?v=-ccxOY9btlw; retrieved July 9,2021), which means that its reach is far greater than that of children's books about the World War II ghetto. The term is so charged with meaning and continues to evolve to such a degree that it was the subject of the February 2, 2021, Conversations/Conversazioni meeting featuring David Nirenberg, the Deborah R. and Edgar D. Jannotta Distinguished Service Professor of Medieval History and Social Thought at the University of Chicago, and Avinoam Shalem, the American Academy in Rome Director. I quote from the announcement: “'Ghetto' emerged as a word to describe a specific late-medieval phenomenon: the creation in Christian cities of segregated and walled neighborhoods in which Jews were required to live. Today its meanings are vaster, and it serves as a metaphor for many different types of containment and segregation. How did these urban spaces emerge? Why did they prove so useful as marginal spaces and a metaphor? And what work do the phenomenon and the metaphor do today?” (American Academy in Rome, 2021). The actual meeting, which I attended, was focused on the medieval ghettos but the Warsaw Ghetto was mentioned in the context of its 'negative' connotations. 
the first result is a new restaurant space opened in 2019 by the culinary collective who call themselves 'Ghetto Gastro': Labyrinth 1.1 in the Bronx. ${ }^{8}$

Nonetheless, the image of the Warsaw Ghetto, of which physical and architectural traces are preciously few, still survives in the textual form: both the survivors as well as others - historians, authors, literary critics - refer to the actual experience as well as to the ghetto as a metaphor. ${ }^{9}$ And it is precisely the metaphorical aspect of the ghetto in its connection to the myth of the labyrinth that interests Rybak the most in his analysis of contemporary Polish children's literature. Rybak's undertaking is as ambitious as it is fraught with risk: the subject of Holocaust representation is demanding for it involves not merely aesthetic criteria but above all ethical ones. The question of how to commemorate the Shoah, how to discuss it, and how not to banalise or belittle it has preoccupied such thinkers as Tzvetan Todorov (1995 - Les Abus de la mémoire), Alvin H. Rosenfeld (2011 - The End of the Holocaust), Ruth R. Wisse (2020 - "The Dark Side of Holocaust Education"), and others. Moreover, for a slim book, Rybak's is filled with interdisciplinary content: beginning with classics, he then delves into Holocaust studies only to move to art history. Simultaneously, his study comes in the wake of 'spatial turn' in literary criticism. More specifically, I would suggest that Rybak's book could be placed in the broader context of what Judith Kasper $(2016)^{10}$ has called a "traumatised space," namely actual places such as death camps and their geographical extensions (e.g. ashes spread widely by the wind) analysed through the lens of literature going as far back

8 Interestingly enough, the article ends with a quotation from the founder, Jon Gray: "We're home," he says. "Let's build," which, at least to me, signals the opposite of the labyrinth. Evidently, the collective use of both labyrinth and ghetto is only vaguely symbolic and intends to engage the public rather than to constitute a reference to the original concepts. Nonetheless, the first comment in the 'conversation' underneath the article states: "I really wish their name wasn't 'Ghetto Gastro.' Couldn't they come up with a better name?” (after Kahn, 2019).

9 Such a use can be a form of appropriation. Michael Rothberg (2019) in The Implicated Subject: Beyond Victims and Perpetrators argues that the concept of the ghetto can also be subject to a public memory: "My particular focus here will be a controversy that arose when a radical American sociology professor sent an email to his undergraduate students in which he declared that 'Gaza is Israel's Warsaw' and forwarded a photo essay with 'parallel images of Nazis and Israelis,' several of which depict the Warsaw Ghetto. Because this controversy is by no means an isolated case, [...] it calls for a critical genealogy of memory discourses" (p. 124). It is not without significance that the cover of Rothberg's book, featuring William Kentridge's 1990 piece entitled Arc/Procession: Develop, Catch Up, Even Surpass, is designed to resemble a partial labyrinth.

10 See also an earlier version of her project as described by Sabine Sütterlin (2014). 
as Dante's Divine Comedy (Alighieri, 1472/2003). For a young scholar, this is quite a spectrum but fortunately Rybak has been shaped by one of the most interdisciplinary Polish academic departments: University of Warsaw's Faculty of "Artes Liberales."

In a telling opening sentence, Rybak (2019) states that "[i]n spite of the Warsaw Ghetto having been liquidated over seventy years ago, one can still happen upon fragments of its wall" (p. 7), thus announcing his ex-post perspective. Rybak comes in the footsteps of many Holocaust scholars before him and, therefore, has a considerable distance, both temporal and emotional, to the events that constitute his subject. His opening statement communicates a sense of surprise: so many years have elapsed and yet some traces remain. Needless to say, the Warsaw Ghetto is not absent because of the number of years that have passed but because it had been purposefully obliterated. It is perhaps the nearly complete lack of Jewish districts in contemporary Polish cities that makes Rybak use the words getto [ghetto] and dzielnica żydowska [Jewish quarter] interchangeably (pp. 14, 15, 26, 50, and others). Were he writing about the Middle Ages, it would have been justified, ${ }^{11}$ but in the context of the Warsaw Ghetto, it is not, since the ghetto was a shuttered urban space, an antechamber to death, ${ }^{12}$ not just a city quarter in the sense in which Diamantkwartier in Antwerp is one. Leociak (2009/2019) quotes Chaim Kaplan as the person who called the German's use of the term Jewish residential quarter "onomastic manipulation" (pp. 91-92). The claim that the Warsaw Ghetto was, in fact, created to be unlike any other quarter or even ghetto, because its final purpose was not to exist, is made by Benjamin Paloff in his 2017 article, provocatively entitled "Can You Tell Me How to Get to the Warsaw Ghetto?":

In speaking of the Warsaw Ghetto, it is important to distinguish it from other historical Jewish ghettos in Central Europe, such as Josefov in Prague or Kazimierz

11 For instance, the German medievalist Alfred Haverkamp (1995) writes as follows: "In this essay I shall avoid the central theme of this volume, namely 'ghetto,' and resort instead to the more neutral concept of 'Jewish quarter.' This concept means no more than a rather large, spatially concentrated Jewish settlement. In this way I wish to avoid a long-standing confusion that is still apparent, even in recent research. This confusion manifests itself, for example, in the Encyclopaedia Judaica under the entries 'Jewish Quarter' and 'Ghetto.' The first asserts that the 'ghetto did not appear as a permanent institution until its introduction in Venice in 1516.' It is, however, conceded that the 'idea of the ghetto in its restricted sense resulted from the tendency of Christianity from the fourth and fifth centuries to isolate the Jews and to humiliate them."' (p. 13; internal quotes from Roth, 1971).

12 "The ghetto was a vestibule for the Final Solution" (Leociak, 2009/2019, p. 83). 
in Krakow. Arising in the Middle Ages and established with specific geographic boundaries, local administration, and legal protections, these minority enclaves were integral parts of their surrounding urban zones, with longstanding, if at times uneasy, relations with the majority population. The historical echo of these ghettos in those used to corral Jews in occupied Europe is largely metaphorical.

Even though the article is accompanied by the author's carefully chosen photographs of the ghetto's material remnants ${ }^{13}$ as well as by images of several artistic interventions, in his analysis, Paloff calls the Warsaw Ghetto "a significance without a site, a lieu de memoire without a lieu," and points to the progressive diminishing of the delimited area leading to its eventual annihilation:

The Seuchensperrgebiet, or 'quarantine zone' established in March 1940 around the Jewish area of the city, with Germans being warned not to enter for fear of disease, was considerably larger than the area walled in and shut off from the rest of the city on November 15. This area was further reduced by several city blocks at a time until the Great Liquidation Action that began on July 22, 1942, during which more than a quarter-million of the Ghetto's inhabitants were deported to the death camp at Treblinka. In August, large sections of what had been the Ghetto were reincorporated into the 'Aryan' city, while an almost equal area within the so-called 'residual Ghetto' was formally declared 'wild' - vast plots of vacant residential space at the heart of the Ghetto's overcrowding.

Residual, vacant, empty: the ghetto's ontological status is a matter of concern to contemporary researchers who focus on its negative space. ${ }^{14}$

13 It so happens that recently POLIN Museum of the History of Polish Jews was hosting an exhibition entitled Tu Muranów, which gathered all manner of artefacts found in the space of the former Warsaw Ghetto. The temporary exhibit was open from June 26, 2020, to March $22,2021$.

14 Leociak (2009/2019) writes: “The destruction of the ghetto was not the destruction of space. That space has remained, but it is empty (though it has been built over with apartment buildings and business complexes), it is stripped bare and dead (though it is buzzing with life). The space survived, though it is somehow hollow, bereft of 'content,' of an 'interior.' The ghetto that was here succumbed to annihilation, but that 'here' remained; it was just eclipsed by another presence. The frames stayed behind, which now contain another reality; a topographical point remained, a cartographic abstraction" (p. 117). Leociak discusses the hermeneutics of empty space: superimposition and co-presence, acts of filling in, unveiling, revealing. We, the post-moderns, know something of the hermeneutics of empty space: 9/11 and the destruction of the World Trade Center towers along with several thousand human beings is, albeit on a much smaller scale, that of the Warsaw Ghetto, an annihilation resulting in an empty space. 
Rybak's book opens with traces: on the tissue of the modern-day Warsaw, he outlines the remnants of the walls and other vestiges of the Warsaw Ghetto as well as various artistic forms of representation of the horror that the ghetto was. Most insightful in this context is Jacek Leociak's (2009/2019) pivotal idea of the "space-after-the-ghetto" (p. 117) which Rybak evokes. As for the notion of the labyrinth, in the discussion of both Sir Arthur Evans's and Hans Georg Wunderlich's theories concerning the Palace of Knossos, the question arises as to what the building's traces represent, their real purpose. Truly pertinent here are Rybak's (2019, p. 43) remarks about the German geologist's scholarly speculations concerning the true use of the labyrinth as a place of mortuary practices (p. 43). Subsequently Rybak shows many shades of meaning of the labyrinth as an analogy used by literary diarists and memoirists in reference to wartime Warsaw, and specifically to the ruins of the ghetto (such as Miron Białoszewski, 1970/2015, in his A Memoir of the Warsaw Uprising), as well as by people who simply wrote down their experiences (e.g. Stanisław Srokowski, quoted by Jacek Leociak, 2009/2019, pp. 92-93). That part of the book is testimony to Rybak's scrupulous attention to the ramifications of the subject under investigation and to his meticulous research. ${ }^{15}$

I do, however, question Rybak's focus on Nathaniel Hawthorne's 1853 retelling of the myth of Theseus in the labyrinth. Taken out of context of the author's oeuvre, his "Minotaur" appears rather odd. Nothing is really terrifying in this tongue-in-cheek tale except perhaps for the monster's voice, halfhuman, half-bovine. While Rybak is justified in mentioning Hawthorne's tale (as a version of the myth written for children), there are others, more à propos because more modern, such as Walter Benjamin's (1931/2014) "The Fall of Herculaneum and Pompeii" from his Radio Stories for Children, ${ }^{16}$ which opens with the figure of the labyrinth. "Have you ever heard of the Minotaur?,"17 Ben-

15 As far as the representation of the labyrinth in the context of fascism and with a child protagonist, there is also Guillermo del Toro's 2006 film Pan's Labyrinth which Rybak does not mention.

16 The labyrinth was Benjamin's (1932/1986) preferred figure, which he used also in the account of his own childhood and youth experiences in Paris: "Paris taught me this art of straying; it fulfilled a dream that had shown its first traces in the labyrinths on the blotting pages of my school exercise books. Nor is it to be denied that I penetrated to its innermost place, the Minotaur's chamber, with the only difference being that this mythological monster had three heads: those of the occupants of the small brothel on rue de la Harpe, in which, summoning my last reserves of strength (and not entirely without an Ariadne's thread), I set my foot” (p. 9).

17 It is remarkable that Benjamin considers several catastrophes as appropriate subjects for his young listeners; in the same collection are: "The Lisbon Earthquake," "Theater Fire in Canton," and "The Railway Disaster at the Firth of Tay." 
jamin asks his young listeners and then uses the analogy of the labyrinth to describe the actual experience of visiting the burnt-out Pompeii: "People visiting modern-day Pompeii could certainly use one of Ariadne's threads: it's the largest labyrinth, the largest maze on Earth. Wherever the eye wanders, it finds nothing but walls and sky. Even 1,800 years ago - before Pompeii was buried alive - it mustn't have been easy to find one's way; for old Pompeii, like Karlsruhe for us, was composed of a complex network of perpendicular streets" (p. 152). Rybak points out that Leociak speaks against the Pompeii analogy in relation to the Warsaw Ghetto: in addition to Vesuvius's explosion being a natural catastrophe, the entire town of Pompeii is still there, impeccably preserved, while the ghetto is not. Leociak is right: no analogy is possible because as a historical phenomenon, the Warsaw Ghetto stands alone. ${ }^{18}$ Nonetheless, the horror of mass death and the fact that the cataclysm could be observed by witnesses make for a distant correspondence. When Stanisław Śreniowski (2005, p. 248; as translated and quoted in Paloff, 2017), a Jewish historian living in hiding on the 'Aryan' side, recalls the vision of the Warsaw Ghetto after the Uprising - "An enormous cap of dark grey smoke above the Extinct City in the Capital maintains, with the weight of its material, the reality of the fiction that is the emptiness: the City in the City, the City that no longer is" - he nearly echoes Pliny the Younger (A.D. 79/1988) writing about Pompeii: "On the landward side a fearful black cloud was rent by forked and quivering bursts of flame, and parted to reveal great tongues of fire, like flashes of lightning magnified in size" (p. 19). The same historian, only seventeen at the time, notes the shrieks, wailing and screaming, and the loss of faith of the city's inhabitants. Nearly two thousand years later, Benjamin recalls the anxiety-provoking experience of losing his companion in the maze of the deserted streets and then getting lost himself.

Before Benjamin, the American writer Mark Twain (Samuel Clemens) visits Pompeii in 1867 during his voyage to Europe, Egypt, and the Holy Land. In The Innocents Abroad, the book account of his experience, Twain (1911) chooses to describe Pompeii as a maze, a labyrinth:

18 "And I also told them that whether they wanted it or not, what happened here will remain in all of us for generations - in Jews, Poles, the French and the Germans, in all those who took part in it in one way or another. Because that's epigenetics, I told them, and they didn't know that it meant passing on messages from generation to generation, not through genes" (A. Edelman, 2017). 
No - Pompeii is no longer a buried city. It is a city of hundreds and hundreds of roofless houses, and a tangled maze of streets where one could easily get lost, without a guide, and have to sleep in some ghostly palace that had known no living tenant since that awful November night of eighteen centuries ago (p. 227).

It is uncanny to read Twain's experience which stands out in an otherwise jocular book. While ready to ridicule everything he encounters in the Old World, including its antiquities, Twain connects to Pompeii in a most human way by identifying with the victims:

The cry of "All aboard - last train for Naples!" woke me up and reminded me that I belonged in the nineteenth century, and was not a dusty mummy, caked with ashes and cinders, eighteen hundred years old. The transition was startling. The idea of a railroad train actually running to old dead Pompeii, and whistling irreverently, and calling for passengers in the most bustling and business-like way, was as strange a thing as one could imagine, and as unpoetical and disagreeable as it was strange (pp. 231-232).

The image of a modern train clashing with the "dead Pompeii" is testimony to Twain's sensitivity. Less than a hundred years later, Polish writers (Zofia Nałkowska, Maria Dąbrowska, Jarosław Iwaszkiewicz, and others) will cross the Warsaw Ghetto on an 'Aryan' streetcar. They, too, experience the irreverence and the strangeness of such passage:

Looking at the burning Ghetto in April 1943, the prominent Polish writer Jarosław Iwaszkiewicz noted in his diary, with horror and despair, that:

there die artists such as Roman Kramsztyk, such close, old friends as Olek Landau, parents of friends such as Pawełek Hertz, Józik Rajnfeld, and we can do nothing. We helplessly watch the dark smoke that rises from their houses, from their bodies. This is extremely difficult to comprehend and to live through. We don't try to understand; we just go on (Brenner, 2014, p. 3).

It would seem that the analogy with ancient Pompeii (or, by extension, with the mythical labyrinth) is one that makes an impression on a sensitive person: lacking the experience, lacking direct contact with the reality of the Ghetto, we, the children and grandchildren of the Shoah generation, could perhaps feel the existential horror vacui within the dead city's walls (Paul, 2011). Such an experience may be more convincing than visiting a museum because it is not a simulacrum: unlike museum models, Pompeii is real. The analogy, however, 
is problematic because both Twain and Benjamin experienced the tragedy of Pompeii vicariously, not in relation to any other hecatomb.

On April 19, 1949, i.e. on the sixth anniversary of the Warsaw Ghetto Uprising, in Western Galilee, the first museum of the Holocaust was opened by Yitzhak (Antek) Zuckerman and several other Ghetto Uprising survivors. It was a modest tent on the grounds of the Kibbutz Lohamei Hagetaot. The actual museum building - recalling in shape a Greek temple (https://www. jewishvirtuallibrary.org/ghetto-fighters-x0027-house; retrieved July 8, 2021) was designed by architect Samuel Bikeles in 1950, and then an addition was put in place by the EKA Architects between 2002-2006, within the existing building. As the architects Zvi Efrat and Meira Kowalsky (n.d.) state, "the conceptual challenge was not to reproduce or simulate, but rather to re-enact the original situation of GFH [Ghetto Fighters House]." The original Eichmann's booth from the trial is housed in the museum - Minotaur-like indeed, even though it is empty. In 1995, Yad LaYeled, a separate museum about the children in the Shoah designed especially for children visitors (10 and above) was added to the complex by architect Ram Karmi: "The plan is based on the image of a whirlpool, leaving no opportunity for escape. The main structure is a truncated, cone-shaped light-shaft, surrounded by a spiraling descending ramp. As one descends, the light - expressing 'life' - fades, until one reaches the lower level where sheer darkness prevails. There, an eternal flame - symbolizing hope - illuminates the exit, the way back to life" (Israel Ministry of Foreign Affairs, 1998). The design of this museum is indeed reminiscent of a labyrinth of sorts, especially since at no time do the visitors get a sense of the whole structure. The content is produced from authentic historical documents (such as children's diaries) and includes an exhibit on the life and works of Janusz Korczak (Henryk Goldszmit). What is less convincing because it smacks of a feeble simulation is the part where the visitors walk through a fake ruined, burned-out street of the ghetto. The building remnants are not on 1:1 scale but smaller which creates the sense of being on stage. The effect is that of a theatrical decoration. Małgorzata Wójcik-Dudek (2019) uses the labyrinth analogy to analyse the King Matt the First space for children in the POLIN Museum in Warsaw, but Rybak does not look at the Yad LaYeled Museum, nor at the Ghetto Fighters' Museum. It would be natural to take them into consideration as they are directly connected to the Warsaw Ghetto and, moreover, employ some of the symbolism Rybak analyses. Last but not least, Yad LaYeled devotes an entire floor of its permanent exhibition to Goldszmit, the pediatrician and children's author whose Ghetto Diary (Korczak, 1978/2003) is conspicuously absent from Rybak's book. 
Rybak (2019) undertakes to see the contemporary representation of the ghetto in Polish children's literature through the lens of a concept from ancient Greek mythology. A problem arises, however, when he seems to confuse the notion of the Holocaust with that of its representation. For instance, he promises to demonstrate "how myth and the Holocaust affect each other" (p. 26; English quote after the book's summary - p. 146). Myth cannot influence the phenomenon of the Holocaust. Its application can, however, influence the representation of the Holocaust. Even though Rybak claims that his book concerns only children's literature about the Holocaust, and not the historical event of the Holocaust (p. 25; he says he follows Leociak's lead on that in footnote 49), nonetheless, just one page later, he does confuse the two. In the conclusion, the same mistaken wording which reveals a lack of conceptual understanding is repeated: "The final parts of my argument are devoted precisely to the consideration of the two-way relation between the myth of the labyrinth and the Holocaust" (p. 117)

Another problem is the arbitrary dissolution of the very notion Rybak (2019) has been defining. Chapter II, in which he has established that the labyrinth is in fact an appropriate metaphor for the cramped, prison-like space of the ghetto, ends in its watered-down version: the labyrinth has become a metaphor for "everyday reality of the occupation, persecution, and extermination" (p. 63). What has happened here? The reader is thrown off the rather carefully built structure in which the victims of the Holocaust are commemorated by labyrinth-like monuments (Yad Vashem, Berlin Jewish Museum) into a vague terrain where "life in the ghetto" is like a labyrinth but so is the general life under occupation. Several pages later, in Chapter III, Rybak again hammers out the notion of the ghetto as a labyrinth which in turn is a metaphor for a "prison without an exit" (p. 65). This seems contradictory to the definition of the Cretan labyrinth he himself describes as a maze not without an exit but rather built in a manner confusing to anyone within its limits, i.e. a true maze. Last but not least, there was an exit from the Warsaw Ghetto: it led, through Umschlagplatz, to death in Treblinka. Therefore, it would behoove the author not to equate the ghetto with a prison where one is "serving a termless sentence" (also p. 65; he quotes Małgorzata Czapiga, 2013, p. 278). The sentence was not termless: it was short because ghettos were built only as temporary structures, antechambers to death.

As for the part of Rybak's book which deals with commemoration through architectural complexes and monuments, it is very compelling until one realises that Rybak simply summarises Katarzyna Witasiak's 2016 article "The Archetype of the Labyrinth in the Architecture of Holocaust Memorials," 
referring only to the memorials she analyses therein. Meanwhile, closer to home than Israel or even Berlin, there are Marian Kołodziej's Labyrinths in Harmęże (https://www.labyrinths.pl/; retrieved December 11, 2020). ${ }^{19}$ Samuel Bak's visionary landscapes are also evocative of the labyrinth and he himself is a survivor of the Vilnius Ghetto (https://www.christies.com/lot/lot-5531390; retrieved December 11,2020). As far as other presence of mythical figures in relation to the Holocaust is concerned, Bracha Ettinger's Eurydice series (19922006) comes to mind as well as her exhibition Facing History in the Pompidou Center in Paris (2010). I mention all these not to say that they are indispensable to Rybak's project, but in a thorough survey of the representation of the Shoah in relation to mythology there is place for those renowned artists.

I have several questions which I would like to ask the author. What does "the oppressiveness of life in the diaspora" (Rybak, 2019, p. 61) mean? Was "everybody" really "buying flowers for their friends going to the ghetto" (p. 66)? Why by page 65 the reader still does not know whether the metaphor of the ghetto as labyrinth - the metaphor of being imprisoned without having committed a crime - means that the Jews are in the situation of the Minotaur? There is a confusion here, a kind of slippage. The Jews are certainly not Theseus, as they cannot leave, although the eponymous protagonist of Jutka's Insomnia (Combrzyńska-Nogala, 2012) is given a skein of wool - by her grandfather - when she goes into hiding. Last but not least, I would like to know how the author comes to use words 'pleasant' and 'unpleasant' in relation to the ghetto: "In children's literature as well staying in the ghetto-labyrinth is not unambiguously perceived as either pleasant or unpleasant" (Rybak, 2019, p. 77). These words simply do not adhere to the reality of the ghetto as the Jews within its walls were not only subject to persecution, they also died of starvation and illness, often in the streets. Leociak uses the word "torture." Moreover, having established beyond doubt that the labyrinth metaphor connotes imprisonment and death, Rybak unnecessarily backtracks and asks himself and his readers whether the space of the ghetto can be "tamed." I am also taken aback by the book's naive conclusion: as long as we do not forget about the Shoah, Rybak writes, "the risk of it happening again is little" (Rybak, 2019, p. 124). This is false logic: Holocaust deniers talk about the Holocaust all the time not to commemorate but to annihilate its truth. ${ }^{20}$

19 Kołodziej was one of the first prisoners of KL Auschwitz.

20 Wisse (2020) in "The Dark Side of Holocaust Education" discusses why universalisation is dangerous. She posits a basic question: "But is there any evidence that Holocaust education decreases hatred of the Jews among those Americans who are susceptible to it? In reality, 
As far as form and style are concerned, my reservation is that the book went to press bearing many traces of having been the author's Master's thesis, including remnants of the thesis proposal: there is the future tense in the account of the book's first chapter (Rybak, 2019, p. 17) when it would be more accurate to say that the classic works are, not will be presented, then again later. By the same token, in many cases Rybak uses the past tense when discussing the plot of the stories, thus unnecessarily complicating the accounts which are customarily kept in the present. Rybak writes about "the abhorrence that the Minotaur causes in Hawthorne" (p. 40), as if indeed one could mistake the tale's narrator for the author especially since this particular tale's narrator is jocular (which Rybak notices and mentions in footnote 33).

There are also colloquialisms (e.g. "[...] takich fragmentów jest całkiem sporo" [there are quite a few such passages] - Rybak, 2019, p. 28) which mar the otherwise formal diction. Vague adjectives such as wielki [great] - "the great epic that is [...] Aeneid," "the great Roman poet Ovid" (p. 32) - are valuations that are out of place in this kind of study (the same is true about "intriguing Metamorphoses," p. 32). When Rybak enumerates authors or critics, he often does it without regard to chronology. Thus, Friedrich von der Leyen (1873-1966) should be mentioned before and not after Mircea Eliade (19071986) and Jack Zipes (who is still alive), especially since Rybak is enumerating them in the context of chronology (p. 23). The same insouciance occurs again in the book's conclusion: "Michał Głowiński, Primo Levi" (p. 123) as if Głowiński wrote before Levi. Sometimes, the vocabulary Rybak employs is simply inadequate. I believe that this is not because the author does not realise the gravity of his subject but rather because he is trying to avoid repetition. Thus, after speaking of the heroic resistance of the Jews, he then mentions their being "brave" [odważni], a much weaker and an inadequate adjective under the rubric. In Polish, the adequate word would be bohaterski [heroic]. Perhaps he is quoting or mistranslating. On p. 35, he writes that the play "was performed on the wooden planks of the theater" [została wystawiona na deskach teatru] which makes for an awkward metaphor when referring to ancient theater. There are also certain repetitive expressions which are common

anti-Semitism in the United States has spread in tandem with increased teaching about the Holocaust. And there is really no sound theoretical underpinning for this expanding educational initiative." Wisse is concerned about the corruption that "begins with the impulse to make the Holocaust a universal symbol of evil, Nazism synonymous with 'hatred,' and Holocaust education a redemptive American pursuit." She also objects to Jews being introduced to the child at their lowest point in history: as suffering victims, reduced to ashes. 
enough in Polish dissertations but should be excised in scholarly publications, such as the redundant phrases on pp. 36-37, and in footnote 33: "It is worthwhile to note" [Warto zwrócić uwagę], "It is worthwhile to add" [Warto dodać] (footnote 30), "in addition" [ $w$ dodatku], and "It is worthwhile to mention" [Warto również wspomnieć] (footnote 35).

Even though the book is thoroughly researched as far as children's literature is concerned, it does contain minor errors and omissions. The author mentions Uri Orlev's 1956/1979 novel Lead Soldiers as the first children's book concerned with the Holocaust, but fails to mention that Orlev was born in Warsaw (in 1931) and survived in the Warsaw Ghetto, both facts relevant to Rybak's subject. Moreover, the 1956 book is not meant for children or young adults - it is a "lyrical autobiography meant for adults" (Shikhmanter, 2014, p. 2, which Rybak, 2019, quotes in footnote 15, p. 16, and which he mentions again in footnote 27). Careless is also the mention about Orlev emigrating after the war to Israel, when Israel did not exist as a state at the time of Orlev's arrival there (it was still the British Mandate Palestine). Theodore Ziolkowski's 2008 book, mentioned in footnote 31, should be discussed in the body of Rybak's book because Ziolkowski's argument is that the labyrinth, used by Botticelli and Dante, surfaces again in modern art only in the 1930s. This is relevant to Rybak's argument because Ziolkowski credits the publication of the six volumes of The Palace of Minos by Sir Arthur Evans (1921-1935) in which the archeologist describes the results of his excavations in Knossos. Other minor typographical errors are perhaps to be expected in a Master's thesis, but should not appear in a book published by a university press: "Kozentrationslager" instead of "Konzentrationslager" (Rybak, 2019, p. 8), while in the footnote to that sentence the word is misspelled in yet another way, namely "Konzentrationslanger." This, again, is a reproach directed to the editor and proofreader as much as to the author. On page 12, footnote 5, the transliteration of Uri Orlev's 1956 book title into Polish should read Hajalej oferet, not Hajalel oferet. Page 12, footnote 6 should read "Johns Hopkins," not "John Hopkins" - once more, a kind of typo that is more likely in Europe. On p. 14, the reader finds an awkward expression "body of children's texts" [korpus tekstów dziecięcych] while on p. 20 - "texts devoted to [...] texts" [teksty poświęcone (...) tekstom] - a clumsy repetition, especially since "text" means very little nowadays. On p. 25 - in the same sentence there are "In addition" [ $W$ dodatku] and "additionally" [co dodatkowo]. On p. 26 - the last sentence of "Aims" contains a grammatical error in the declension: poświęcone relacji łączących mit [devoted to the relations connecting myth]. It should read either poświęcone relacji łączacej mit” or "poświęcone 
relacjom łaczacym mit." None of these typographical or other errors obscure the book's gist - they simply suggest that the practice of proofreading is a vanishing one.

In the book's somewhat hasty conclusion, Rybak claims that drawing an analogy between the ghetto and the ancient labyrinth belies the Shoah's uniqueness. But the fact of comparing the Holocaust or its elements to an ancient myth does not do that. Why should it? Many Holocaust authors use analogies from antiquity. Neither is it true that mere taking up of the subject of the Holocaust will somehow prevent its reoccurrence. ${ }^{21}$ It is, however, imperative to ensure that Holocaust itself does not become a myth. Rybak's book does not convince me that children's literature can indeed prevent the mythisation of the Holocaust, but it does prove beyond doubt the perseverance of myth.

\section{References}

Alighieri, D. (2003). The divine comedy: The Inferno, the Purgatorio, and the Paradiso (J. Ciardi, Trans.). New American Library. (Original work published 1472).

American Academy in Rome. (2021, February 2). David Nirenberg \& Avinoam Shalem - on ghettoes: medieval, modern, and metaphorical. Retrieved July 8, 2021, from https://aarome.org/events/calendar/david-nirenberg-avinoam-shalem-ghettoesmedieval-modern-metaphorical.

Benjamin, W. (1986). A Berlin chronicle. In Reflections: Essays, aphorisms, autobiographical writings (E. Jephcott, Trans., P. Demetz, Ed. \& Intro., pp. 3-60). Shocken. (Original work published 1932).

Benjamin, W. (2014). The fall of Herculaneum and Pompeii. In Radio Benjamin (J. Lutes, Trans., L. Rosenthal, Ed., pp. 152-157). Verso. (Original work broadcasted 1931).

Białoszewski, M. (2015). A memoir of the Warsaw Uprising (M. G. Levine, Trans.). New York Review Books. (Original work published 1970).

21 "It is often presumed that, if we remember the evil committed in the past, we can avoid it today. However, there is no reason to conclude that evil is generally on the decline. If we observe the process of production of narratives about evil and good, we can identify four main roles: on the one hand (i) the villain and (ii) his victim; on the other (iii) the hero and (iv) his beneficiaries. To this, one should add the distinction between (a) us (our community) and (b) the others (those who are foreign, different or enemies). The sterility of calls to remember is rooted in our constant identification with heroes or victims and the extreme distance we put between evildoers and ourselves" (Todorov, 2009, pp. 447-462). 
Brenner, R. (2014). The ethics of witnessing: The Holocaust in Polish writers' diaries from Warsaw, 1939-1945. Northwestern University Press. https://doi.org/10.2307/j. ctv43vsp2.

Buryła, S. (2016). Wokół Zagłady. Szkice o literaturze Holokaustu. TAiWPN Universitas.

Canin, M. (2018). Przez ruiny i zgliszcza. Podróż po stu zgładzonych gminach żydowskich w Polsce (M. Adamczyk-Garbowska, Trans.). Nisza. (Original work published 1952).

Combrzyńska-Nogala, D. (2012). Bezsenność Jutki. Literatura.

Czapiga, M. (2013). Labirynt: inicjacja, podróż i zbłądzenie. Figura ludzkiego losu w kulturze europejskiej. Wydawnictwo UWr.

del Toro, G. (Director). (2006). El laberinto del fauno [Pan's labyrinth] [Motion picture]. Picturehouse \& Warner Bros.

Edelman, A. (2017, November 29). Wnuczki. Zeszyty Literackie. Retrieved February 14, 2021, from https://www.zeszytyliterackie.pl/aleksander-edelman-wnuczki/?cli_ action $=1625766220.757$.

Edelman, M. (2004, August 6). The ghetto fights. Center for Programs in Contemporary Writing at the University of Pennsylvania. Retrieved January 31, 2021, from https://www.writing.upenn.edu/ afilreis/Holocaust/warsaw-uprising.html. (Original work published 1945).

[Efrat, Z., \& Kowalsky, M.]. (n.d.). Ghetto Fighters' House Museum. Efrat-Kowalsky Architects. Retrieved July 8, 2021, from http://www.efrat-kowalsky.co.il/project/2006-ghetto-fighters-museum/.

Evans, A. (1921-1935). The Palace of Minos: A comparative account of the successive stages of the early Cretan civilization as illustrated by the discoveries at Knossos (vols. 1-6). Macmillan.

Franklin, R. (2018, July 16). How should children's books deal with the Holocaust. New Yorker. Retrieved January 31, 2021, from https://www.newyorker.com/magazine/2018/07/23/how-should-childrens-books-deal-with-the-holocaust.

Haverkamp, A. (1995). The Jewish quarters in German towns during the late Middle Ages. In R. Po-Chia Hsia \& H. Lehmann (Eds.), In and out of the Ghetto: JewishGentile relations in late medieval and early modern Germany (pp. 13-28). Cambridge University Press.

Hawthorne, N. (1853). The Minotaur. In Tanglewood tales for boys and girls: Being a second wonder book (pp. 19-70). Ticknor, Reed, and Fields.

Israel Ministry of Foreign Affairs. (1998, August 25). Encounters - Yad Layeled Museum. Retrieved July 8, 2021, from https://mfa.gov.il/mfa/abouttheministry/publications/pages/encounters- yad layeled museum.aspx.

Kahn, J. (2019, January 7). Ghetto Gastro opens Labyrinth 1.1, their new HQ in the Bronx. The Wall Street Journal. Retrieved January 21, 2021, from https://www. 
wsj.com/articles/ghetto-gastro-opens-labyrinth-1-1-their-new-hq-in-thebronx-11546877031.

Kali [Gutkowski, K. M.]. (2018). 30 KMH [Song]. On V8T [Album]. Ganja Mafia Label.

Kasper, J. (2016). Der traumatisierte Raum. Insistenz, Inschrift, Montage bei Freud, Levi, Kertész, Sebald und Dante. De Gruyter.

Kimmel, E. A. (1977). Confronting the ovens: The Holocaust and juvenile fiction. The Horn Book Magazine, 53, 84-91.

Korczak, J. (2003). Ghetto diary (J. Bachrach \& B. J. Lifton, Trans., B. J. Lifton, Intro.). Yale University Press. (Original work published 1978).

Leociak, P. (2019). Limit experiences: A study of twentieth-century forms of representation (A. Shannon, Trans.). Peter Lang. (Original work published 2009).

Orlev, U. (1980). The lead soldiers: A novel (H. Halkin, Trans.). Taplinger. (Original work published 1956).

Paloff, B. (2017). Can you tell me how to get to the Warsaw Ghetto? Modernism/modernity, 24(3). https://doi.org/10.1353/mod.2017.0054.

Paul, J. (2011). Pompeii, the Holocaust, and the Second World War. In S. Hales \& J. Paul (Eds.), Pompeii in the public imagination from its rediscovery to today (pp. 340-355). Oxford University Press. https://doi.org/10.1093/acprof:oso bl/9780199569366.001.0001.

Pew Research Center. (2020, January 22). What Americans know about the Holocaust. Retrieved February 15, 2021, from https://www.pewforum.org/2020/01/22/whatamericans-know-about-the-holocaust/.

Pliny the Younger. (1988). The eruption of Vesuvius, August $24^{\text {th }}$ AD 79. In J. Carey (Ed.), Eyewitness to history (pp. 19-20). Harvard University Press. (Original work written A.D. 79).

Rosenfeld, A. H. (2011). The end of the Holocaust. Indiana University Press.

Roth, C. (1971). Jewish quarter. In Encyclopaedia Judaica (vol. 10). Macmillan.

Rothberg, M. (2019). The implicated subject: Beyond victims and perpetrators. Stanford University Press.

Rybak, K. (2016-2020). Oczami dziecka. Zagłada w polskiej literaturze dziecięcej i młodzieżowej po roku 1989. Retrieved July 9, 2021, from https://oczamidziecka.al.uw. edu.pl/.

Rybak, K. (2019). Dzieciństwo w labiryncie getta. Recepcja mitu labiryntu w polskiej literaturze dziecięcej o Zagładzie. Wydawnictwa UW.

Śreniowski, S. (2005). Z księgi obłędu i ohydy (J. Leociak, Trans.). Zagłada Żydów. Studia i Materialy, 1, 246-250. https://doi.org/10.32927/ZZSiM.159.

Sütterlin, S. (2014, December 19). Literature as nourishment - research on a new spatial understanding of the Holocaust (S. Voigt, Trans.). University of Potsdam. Retrieved January 31, 2021, from https://www.uni-potsdam.de/en/ 
headlines-and-featured-stories/detail/2014-12-19-literature-as-nourishment-research-on-a-new-spatial-understanding-of-the-holocaust.

Todorov, T. (1995). Les Abus de la mémoire. Arléa.

Todorov, T. (2009). Memory as remedy for evil. Journal of International Criminal Justice, 7(3), 447-462. https://doi.org/10.1093/jicj/mqp017.

Tomczok, M. (2017). Czyja dzisiaj jest Zagłada? Retoryka - ideologia - popkultura. Wydawnictwo IBL PAN.

Twain, M. (1911). The innocents abroad. Grosset and Dunlap. (Original work published 1869).

Wisse, R. R. (2020). The dark side of Holocaust education. National Affairs, 48. Retrieved February 2, 2021, from https://www.nationalaffairs.com/publications/detail/the-dark-side-of-holocaust-education.

Witasiak, K. (2016). The archetype of the labyrinth in the architecture of holocaust memorials. Czasopismo Techniczne, 8(2A), 253-260. https://doi.org/10.4467/2353 737XCT.16.190.5801.

Wójcik-Dudek, M. (2019). Król Korczak w Muzeum Historii Żydów Polskich POLIN. Koncepcje pedagogiczne Janusza Korczaka a muzealne przestrzenie. Nowa Biblioteka, 35(4), 7-27. https://doi.org/10.31261/NB.2019.35.01.

Wójcik-Dudek, M. (2020). W labiryncie biblioteczki Shoah. ArtPapier, 386(2). Retrieved January 15, 2021, from http://artpapier.com/index.php?page=artykul\&wy danie $=386 \&$ artykul $=7711 \& \mathrm{~kat}=15$.

Wołk, M. (2019). Czy lubimy czytać o Szoa? Narracje o Zagładzie, 5, 379-390. https:// doi.org/10.31261/NoZ.2019.05.21.

Yolen, J. (2018). Mapping the bones. Philomel.

Ziolkowski, T. (2008). Minos and the moderns: Cretan myth in twentieth-century literature and art. Oxford University Press. 